\title{
Influence of Sex on the Hematological and Morphometric Parameters of Cyprinus Carpio (Linnaeus, 1758) from Shkodra Lake
}

\author{
Prof.As.Dr. Suzana Golemi \\ Dr. Neira Medja \\ Dr. Donalda Lacej \\ University "Luigj Gurakuqi"of Shkodër, Albania \\ Department of Biology - Chemistry, Faculty of Natural Sciences, \\ E-mail: zanakuci@yahoo.com
}

Doi:10.5901/ajis.2013.v2n8p45

\begin{abstract}
The aim of the presents study was to obtain the influence of sex on some parameters of Cyprinus carpio (Linnaeus, 1758). The study has been carried out during spawning migration in the period March 2011 - May 2011 and involved 60 healthy individuals of fish, randomly collected. The specimens were weighed and measured. Blood samples were taken to determine hematocrit, hemoglobin, erythrocyte count and erythrocyte indices: mean corpuscular volume, mean corpuscular hemoglobin and mean corpuscular hemoglobin concentration. The mean values of blood indices and morphometric parameters were determinate annually for male and female. Comparison of blood parameters was performed according to sex differences. The results of this study showed that male fish have higher values of hemoglobin, hematocrit, and erythrocyte count, than female. Statistical analysis revealed that differences in hematological and morphometric parameters between males and females were significant.
\end{abstract}

Keyword: cyprinus carpio, hematological indices, morphometric parameters.

\section{Introduction}

Cyprinidae are a large family of freshwater fishes that comprise the carps, the true minnows, and their relatives. Commonly called the carp family or the minnow family, its members are also known as Cyprinids. It is the largest fish family and the largest family of vertebrate animals in general, with over 2,400 species in about 220 genera. Common carp is hardy and tolerant of wide variety of conditions but generally favor large water bodies with slow flowing or standing water and soft bottom sediments. They are omnivorous feeding mainly on aquatic insects, crustacean's annelids, mollusks. Common carp is a hardy fish and adapted almost to all the environments.

The important place of cipriniculture in aquaculture is gave by the big quantity of Cyprinids realized in hatcheries, the number of species, the improved natural trophic recourses, the plasticity and the rigidity at medium conditions, the good capitalization of folder, the quality of food's input and the low cost price.

The studies about Shkodra carp and its forms present scientific interest for researches of the region. There are few studies about normal hematological and biochemistry indices of Shkodra carp, so the evaluation of them in Cyrinus carpio will serve as a good tool of monitoring stress situates diagnostic of pathologies. (Golemi and Lacej, 2012.).

Sex of the fish may also influence the blood parameters. Studies on sexually matured gold fish (Carrassius auratus) (Summerfeld, 1967), brook trout (Salvelinus fontinalis) and brown trout (Salmo gairdneri) (Sniezsko, 1960) showed that males consistenly had higher packed cell volume values than the females and suggested the need to separate blood component data on the basis of sex to avoid attributing sex differences to other factors.

The goal of this study was to determinate the effect of sex on hematological indices and morphometric parameters of Cyprinus carpio form Shkodra Lake with the hope of providing some useful information on this aspect of its biology.

\section{Methods}

\subsection{Biological indices}

Common carp (Cyprinus carpio) used in this study were captured from different station in Albanian side of Shkodra Lake. Sixty fish were weighed and measured 28 males, $2598 \pm 124$ gram and $43.3 \pm 3.2 \mathrm{~cm}$ and 32 females, $2954 \pm 0.22$ gram 
and $45.4 \pm 0.36 \mathrm{~mm}$ (mean values and standard deviation).

Morphometric indices measured were body weight $(W)$, maximal length $(L)$, length till the tail bifurcation $(I)$, length till the end of scales $(\mathrm{C})$ and maximal body height $(\mathrm{H})$.

Blood samples were collected from 28 males and 32 females. The collection was done by caudal vein of 60 fish specimens with $5 \mathrm{ml}$ sterile syringes and kept at ice-could tubes to with heparin (70 $\mathrm{IU} \mathrm{ml-1}$ had been added (according to Ballarin et al., 2004) . samples have been taken after anesthesia with MS 222; $0.1^{-1}$ water (according to Handy \& Depledge, 2000).

\subsection{Haematological analysis}

The analysed of haematological parameters have been: $\mathrm{RBC}, \mathrm{Hb}, \mathrm{Hct}, \mathrm{MCV}, \mathrm{MCH}$, and $\mathrm{MCHC}$ WBC, lymphocytes, monocytes, granulocytes. Haematological parameters were carried out using the HumaCount 30TS is a fully automated 3-part differential cell counter. Reagents that used analyser supplied by Human GmbH. Reagents are: HC-DILUENT: Isotonic saline solution used to dilute whole blood specimens and to rinse the fluidic system between measuring procedures. HC-LYSE: Used to prepare blood hemolysate for 3-part WBC differential and for total WBC and HGB measurement. CLEANER: Used to perform cleaning process of the fluidics. Significance level was defined as $p<0.05$.

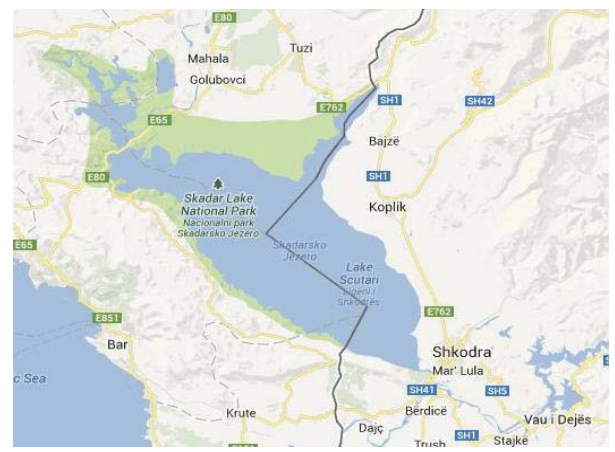

Figure 1. Investigation area

\subsection{Statistical parameters used.}

Differences in hematological parameters between males and females fish were statistically analyzed by student's test $(p<0.05)$. Means and standard deviation (SD) were calculated for each parameters measured. Each parameter was determined using MINITAB 16.

\section{Results and discussion}

\subsection{Basic changes hematological of common carp Cyprinus carpio regardless of sex}

The result of the hematological indices for males and females are shown in table 1: Age $5+$, mean hemoglobin $(\mathrm{Hb})$ $9.55 \pm 0.25$ and $6.54 \pm 0.56 \mathrm{~g} / \mathrm{dl}$; mean hematocrit (packed cell volume, Hct) $32.27 \pm 0.2 \% ; 25.35 \pm 1.2$, and the number of red blood cells (RBCc) $1.95 \pm 0.42,1.56 \pm 0.24 \mathrm{cell} / \mathrm{s} / \mathrm{ml}$ : the number of leucocytes (WBCc) $11.92 \pm 0.18,18.51 \pm 1.35 \mathrm{cell} / \mathrm{s} / \mathrm{ml}$;

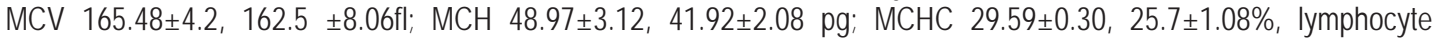
$68.5 \pm 1.21,72.8 \pm 2.13 \%$;neotrophile $4.3 \pm 0.20,7.6 \pm 0.20 \%$; monocyte $17.1 \pm 0.47,18.5 \pm 1.32 \%$ respectively. There were significant differences. 
Table 1. Hematological profile of Cyprinus carpio spawners (mean \pm DS)

\begin{tabular}{|l|c|c|c|c|}
\hline Parameters & N & Female & N & Male \\
\hline $\mathrm{RBC}\left(10^{6} / \mathrm{mm}^{3}\right)$ & 32 & $1.56 \pm 0.24$ & 28 & $1.95 \pm 0.42$ \\
\hline $\mathrm{Hb}(\mathrm{g} / \mathrm{dl}))$ & 32 & $6.54 \pm 0.56$ & 28 & $9.55 \pm 0.25$ \\
\hline $\mathrm{Hct}(\%)$ & 32 & $25.35 \pm 1.2$ & 28 & $32.27 \pm 0.2$ \\
\hline $\mathrm{MCV}\left(\mathrm{mm}^{3}\right)$ & 32 & $162.5 \pm 8.06$ & 28 & $165.48 \pm 4.2$ \\
\hline $\mathrm{MCH}(\mathrm{pg})$ & 32 & $41.92 \pm 2.08$ & 28 & $48.97 \pm 3.12$ \\
\hline $\mathrm{MCHC}(\mathrm{g} / \mathrm{dl})$ & 32 & $25.7 \pm 1.08$ & 28 & $29.59 \pm 0.30$ \\
\hline $\mathrm{WBC}\left(10^{3} / \mathrm{mm}^{3}\right)$ & 32 & $18.51 \pm 1.35$ & 28 & $11.92 \pm 0.18$ \\
\hline Lymphocytes (\%) & 32 & $72.8 \pm 2.13$ & 28 & $68.5 \pm 1.21$ \\
\hline Neutrophils (\%) & 32 & $7.6 \pm 0.20$ & 28 & $4.3 \pm 0.20$ \\
\hline Monocytes (\%) & 32 & $18.5 \pm 1.32$ & 28 & $17.1 \pm 0.47$ \\
\hline
\end{tabular}

Statically significant $(P<0.05)$

Note: RBCc-red blood cell count; Hb-hemoglobin concentration; Hct-hematocrit, MCV- mean corpuscular volume, MCH-mean corpuscular hemoglobin;

MCHC-mean corpuscularhemoglobin concentration, WBCc- whiteblood cell count,

Mean values of Cyprinus carpio hematological indices are presented in histograms below and they represent their relation by sex. Hct is higher in male (32.27 $\pm 0.2 \%)$ than female $(25.35 \pm 1.2 \%)$ as shows figure 2 . The result obtained by different authos are the same, so this metabolic index is higher during all over the year in male than female (Etim L, et al.1999, Ballarin, L, et al 2004, Beqiraj,D et al 2011). They recommended in consideration the sex to avoid its influence from other factors.

High level of Hct is result of higher metabolism in male than female (Jawad et al, Kori-Siakpere et al 2005, Beqiraj et al 2009. These differences on hematological data depend by different needs of oxygen in male and female, especially in reproduction period.

Figure 3 shown that value of RBC, is higher in male $\left(1.95 \pm 0.42 \times 10^{6} / \mathrm{mm}^{3}\right)$ than female $\left(6.54 \pm 0.56 \times 10^{6} / \mathrm{mm}^{3}\right)$ while value of WBC is higher in female $\left(18.51 \pm 1.35 \times 10^{3} / \mathrm{mm}^{3}\right)$ than male $\left(11.92 \pm 0.18 \times 10^{3} / \mathrm{mm}^{3}\right)$.

Higher values of some hematological indices for male than females are caused by varying activity of erythropoietin. Testosterones, the male sex hormones, stimulate its production while estrogens, the female hormones, have a suppressing effect (Trojan, 2003). This conclusion is in accordance with other authors (Kori-Siakpere, 2005) they are comparable with ones of the other species as well as.

\subsection{Sex-related changes on morph metric data of common carp Cyprinus carpio.}

Total weight, maximal length, length till the tail bifurcation, length till the end of scales and maximal body height were determined in common carp Cyprinus carpio the result of them are presented in table 2.

Table 2. Morphological indices level in freshwater fish Cyprinus carpio.

\begin{tabular}{lcccc}
\hline Parameters & N & Female & N & Male \\
\hline & & & & \\
Age(year) & 32 & $5+$ & 28 & $5+$ \\
Weight $(\mathrm{W})$ & 32 & $2954 \pm 0.22$ & 28 & $2598 \pm 124$ \\
Length $(\mathrm{L})$ & 32 & $45.4 \pm 0.36$ & 28 & $43.3 \pm 3.2$ \\
Length till the tail bifurcation $(\mathrm{H})$ & 32 & $12.5 \pm 2.01$ & 28 & $10.18 \pm 2.1$ \\
Length till the end of scales (C) & 32 & $43.2 \pm 6.01$ & 28 & $36.71 . \pm 305$ \\
Maximal body height $(\mathrm{I})$ & 32 & $39.1 \pm 1.23$ & 28 & $41.42 \pm 0.56$ \\
\hline
\end{tabular}

Higher values of morph metric parameters of Cyprinus carpio ( body weight, length, length till the tail bifurcation, length till the end of scales, maximal body height ) were observed in females than males, as we have shown in table 2, figure 4 and 5. 


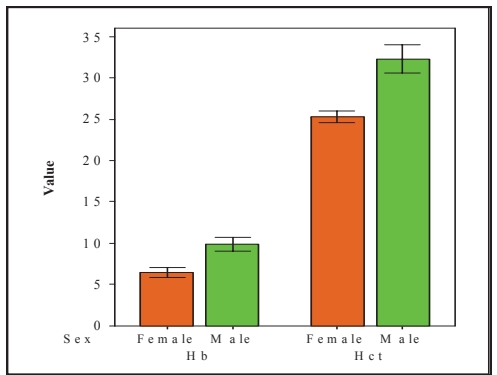

Figure 2. Comparison between males and females in hemoglobin concentration $(\mathrm{Hb})$ and hematocrit value (Hct).

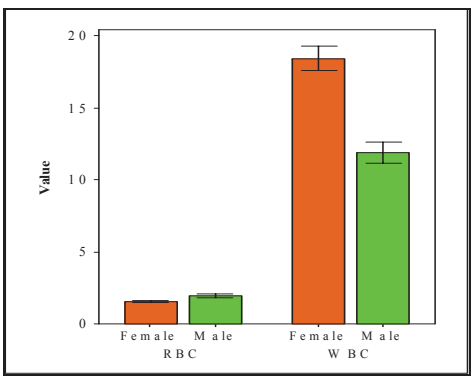

Figure 3. Comparison between males and females in red blood cells (RBC, x 100) and white blood cells (WBC).

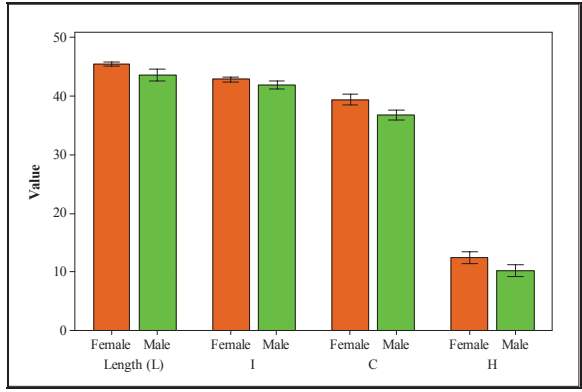

Figure 4. Comparison between males and females in morphometric parameters.

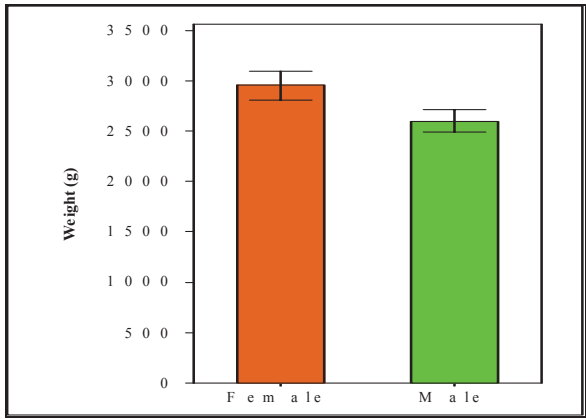

Figure 5. Comparison between males and females in weight. 
Sex has an important in growth of Cyprinus carpio. It has good correlations with metabolic activity and the oxygenation of the water. Authors reported that female's hypothalamus - hypophyse system has an important role in growth and reproduction of them. On the other hand, there are different environment factors influenced in it (Beqiraj z., et al 2009)

The results of this study showed that sex (condition factor) has an important influence on average value of weight, length, maximal body height, in carp. There are significant statistically differences of weight, length, maximal body height mean values between two sexes of Cyprinus carpio.

\section{Conclusion}

In conclusion:

- Sex has effect on Hct, Hb, RBC and WBC in Cyprinus carpio.

- Male fish have higher values of parameters than female, and there are significant differences between the sexes.

- Suggest that such differences between sexes may be related to the genetic differences to the metabolic rates which are higher in males than in females.

- Sex factor has an important effect on morph metric parameters.

This study revealed that the sex of fish may exert some degrees of influence on some of hematological characteristics and morph metric parameters of Cyprinus carpio and hence the need to reckon with these factors in the assessment and reporting of the hematological indices of this fish species. Hence, this gives valuable information on health of economically important fish species Cyprinus carpio.

\section{References}

Ballarin L, Oro M, Bertotto D, Libertini A, Franceson A, Barnaro A, (2004)

Hematological parameters in Umbrina Cirrosa (Teleostei, Scienidae): A comparison between diploid and triploid specimens. Comparative Biochem. \& Physiology. Part A, 138: 45-51

Etim L, Ekanem SB, Utim A (1999). Haemotological profiles of two species of catfish, Chrysicthys nigrodigitatus and Chrysicthys furcatus from the Great Kwa River, Nig. Global J. Pure Appl. Sci. 5(1): 1-8.

Handy RD, Depledge MH, (2000) Physiological Responses: Their measurement and use as environmental biomarkers in ecotoxicology. Ecotoxicology. 8, 329-349.

Jawed LA \& Ktoner A. 2007. Incidence of lordosis in Ö the freshwater mullet, Liza abu (Heckel, 1843) co-llected from Atatürk Dam Lake, Turkey. Anales de Biologia 29: 105-113

Kandemir S, Dogru M, Orun I, Dogru A, Altas L, Erdogan, K, Orun G., Polat N, (2010) Determination of Heavy Metal Levels, Oxidative Status, Biochemical and Hematological Parameters in Cyprinus carpio L., 1758 from Bafra (Samsun) Fish Lakes. J. Animal \& Vet. Adv. 9, 617-622

Nemcsok J, Boross L, (1982) Comparative studies on the sensitivity of different fish species to metal pollution. Acta. Biol Hung 33, 23-7.

O. Kori-Siakpere,J.E G. Ake and E.Idoge @2005 Haematological characteristics of the African snake head, Parachanna obscura. African Journal of Biotechnology Vol.4(6),pp.527530,-5315Academic Journals.

S. Golemi, Donalda Laçej, Biochemical and Hematological Parameters in the Fresh Water Fish, Cyprinus carpio (Linnaeus, 1758) of Lake Shkodra (Albania) J. Int. Environmental Application \& Science, Vol. 7 (5): 998-1002 (2012)

Snieszko S (1960). Microhaematocrit as a tool in fisheries management. Special Scientific Report-Fisheries. No.314, p. 15.

Trojan, S. 2003. Medical physiology, Grada publishing. Prague, 771 pp, (in Czech). 